\title{
The influence of organization culture on teacher performance of elementary school
}

\author{
Ayu Tahnia ${ }^{1}$, Happy Fitria ${ }^{2}$, Achmad Wahidy ${ }^{2}$ \\ ${ }^{1}$ Sekolah Dasar Negeri 10 Rambutan, Jakarta, Indonesia \\ ${ }^{2}$ Universitas PGRI Palembang, Indonesia
}

\begin{tabular}{l}
\hline Article Info \\
\hline Article history: \\
Received Jul $11^{\text {th }}, 2021$ \\
Revised Aug $15^{\text {th }}, 2021$ \\
Accepted Aug 30,2021 \\
\hline
\end{tabular}

\section{Keyword:}

Culture organization

Teacher performance

\begin{abstract}
This study aims to discover the significant influence of Organization Culture on teacher performance in cluster 1 Rambutan Subdistrict, Banyuasin Regency. This research uses quantitative methods. Data collection techniques using questionnaires and documentation. The data was analyzed using multiple linear regression formulas. The results of this study show that there is a significant influence of Organization Culture on teacher performance of elementary school with a t count value of 4,182 and t table of 1,998 where $t$ count $>t$ table then $\mathrm{Ha} 2$ received. The conclusion of this research is that good organization culture where they would actualized teacher performance.
\end{abstract}

(C) 2021 The Authors. Published by IICET.

This is an open access article under the CC BY-NC-SA license

(https://creativecommons.org/licenses/by-nc-sa/4.0

\section{Corresponding Author:}

Tahnia, A.,

Sekolah Dasar Negeri 10 Rambutan, Jakarta, Indonesia

Email: ayutahnia@gmail.com

\section{Introduction}

The advancement of a country can be understood by the degree to which the devotion of a society, nation or state is to the implementation of national education. Through education, an individual will be prepared to have a variety of skills, values and attitudes required to function productively. School for the achievement of national growth priorities as an educational agency. Human resources, consisting of the principal, teachers, students, administrative personnel, and other educational staff in the management of the school organization, rely on one of the successful educational goals in schools. Therefore, in the school setting, the components of organizational representatives have an important role to play in the advancement of education.Organizational culture will be formed by the relationship between members. Organizational culture can be described in basic terms as a way of thought, a way of working, a way of handling employees in the execution of their respective duties.

Addition, success is said to be the product of organizational cultural values, indicating that performance is often a representation of current cultural values. As a self-identity and also as a sensation of pride in the school, each school must establish its own school culture. In the general community, school culture is a trait, character or character and picture of the school.

In the general community, school culture is a feature, character or character and identity of the school. Superior quality work and work may be realized if it is backed by superior quality intellectual resources. A 
school culture would mean the strength of these intellectual capital. . The core values of school culture are usually more philosophical and even somewhat similar to emphasizing the qualities that are the character of a school. Teacher assessments carried out by school supervisors through supervision are expected to improve teacher performance. With regard to the teacher performance standards, as quoted [1] in the guide book for teacher performance appraisal by supervisors, he explained that: "Teacher performance standards are related to the quality of teachers in carrying out their duties, such as: (1) working with students individually, 2) learning preparation and planning, (3) utilization of instructional media, (4) involving students in various learning experiences, and (5) active leadership from the teacher. But in fact, many teachers in the classroom irregularly supply their students with material. Without paying attention to the learning process and learning performance, the content taught is monotonous. For example, the teacher didn't charge a syllabus, the teacher did not prepare an annual curriculum schedule, the teacher did not plan a learning model design for classroom management, and so on. Therefore, the role of the teacher is very important, like the opinion of [2] where the teacher is the main organizer of school culture to create students with positive habits. Professional intellectual resources and one of the determinants of success in achieving educational objectives are teachers as educators, while teachers are responsible for interacting with students, offering direction, education, teaching and experience that will deliver the desired graduates. Of course, by improving organizational culture and leadership, the performance of teachers can increase. Organizational culture has a significant relationship with the performance of teaching staff, as well as the supervision of the principal which has a significant effect on the performance of teaching staff. The goal to be achieved in this context is the creation of teacher performance. [3] teachers greatly influence the success of education through student learning outcomes. Because the success of school reform is determined by the teacher as the learning leader, the facilitator and as the center of learning initiatives.

Teachers must also be mindful of improving their performance internally by self-development and should not need to rely on the principal's initiative alone. Although teachers receive guidance from various groups, particularly school principals, to improve the professional performance of a teacher in the implementation of professional duties. The quality of education is determined by the performance of the teacher for each student. If the better the teacher's performance, the better the quality of education produced will be. So that teachers who have good performance, the results of the teaching and learning process that are obtained will also be good. Therefore, performance plays an important role in achieving optimal teaching goals. Given the important role of this performance, schools need to improve teacher performance so that teaching objectives can be maximally achieved. [4] explains that between individuals and the environment there must be an interaction process that influences one another. A behavior indirectly affects the environment, either positively or negatively. It is said to be positive if the behavior has a good impact on the environment; Likewise, the opposite is said to be negative because it has a bad influence on the environment.

Teachers must also be mindful of improving their performance internally by self-development and should not need to rely on the principal's initiative alone. Although teachers receive guidance from various groups, particularly school principals, to improve the professional performance of a teacher in the implementation of professional duties.

The culture, therefore, has an effect on the patterns of individual behaviour. So the presence of a strong organizational culture has a good effect on other teachers as well. A good organization will be reflected in the good conduct of the organization's members, which in turn will slow down the achievement of the objectives mutually set by the organization in question. According to Laksono [5] a conducive school organizational culture will appear or be reflected in the school organizational structure, school task descriptions, school work systems and procedures, employees, policies and rules, school rules, leadership and relationships, events or rituals, and the physical appearance of the school which also grows and develops. [6] that if organizational culture prioritizes discipline, creativity, cooperation, equality, and the birth of fresh innovative ideas, then in a short time the organization will experience a significant increase. Therefore, teacher performance can also be formed from the influence of the school culture in the school where he teaches. Through boundaries forming patterns of values, principles, traditions and habits that are formed in the school environment, it will encourage the emergence of good attitudes and behavior of school members [7].

\section{Method}

\section{Types of research}

[8] Clarifies that quantitative analysis is a research methodology that needs numbers to be used, beginning with data collection, data interpretation, and results appearance. And this research method uses the partial correlation method, partial correlation is used for analysis or hypothesis testing if the researcher intends to 
know the effect or relationship of the independent and dependent variables, where one of the independent variables is controlled or made permanent [9].

\section{Research Subjects and Data}

The samples in this study were 64 elementary school teachers in Cluster 1, Rambutan District, Banyuasin Regency. Determination of the sample in this study using the Cluster Sampilng Technique. Cluster Sampilng is a sampling technique based on clusters or classes [10]. Organizational culture (X) on teacher performance is the variable for quantitative analysis $(\mathrm{Y})$. In this research, through hypothesis testing as a decision maker through Partial Test and Linear Regression using the SPSS application version 25, the data analysis technique used is the product moment correlation technique.

\section{Results and Discussions}

The results of the normality test show that the One-Sample Kolmogorov-Smirnov Test shows the sig value. (2tailed) of 0.200 . So it can be stated that the significance value is $0.200>0.05$, which means that the data is normally distributed. Thus, it can be stated that all data are normally distributed. The results of the homogeneity test showed that the significance value of organizational culture was 0.311 more than $0.05(0.311$ $<0.05)$. Thus, from the results of these calculations it can be concluded that the group data comes from the same data or is declared homogeneous.

Based on the results of the Linearity test, the $\mathrm{F}$ count was $0.582<\mathrm{F}$ table 3.15 . Because the calculated $\mathrm{F}$ value is smaller than the $\mathrm{F}$ table value, it can be concluded that there is a significant linear relationship between the organizational culture variable $(\mathrm{X})$ and the teacher performance variable $(\mathrm{Y})$ and the Organizational Culture Test $(\mathrm{X})$ is 1.331 less than $10.00(1.331<10.00)$. So it is concluded that there is no multicollinearity between variables.

Organizational culture $(\mathrm{X})$ on teacher performance is the variable for quantitative analysis $(\mathrm{Y})$. In this research, through hypothesis testing as a decision maker through Partial Test and Linear Regression using the SPSS application version 25 , the data analysis technique used is the product moment correlation technique. As well as the heteroscedasticity test, it is known that the significance value of the organizational culture variable $(\mathrm{X})$ is 0.464 more than $0.005(0.464>0.005)$. So that it can be stated that there are no symptoms or heteroscedastity problems. To test the hypothesis, it is carried out using simple linear regression calculations based on the number of questionnaire scores obtained from 64 respondents, the following are the results.

Table $1<$ Simple Linear Regression Coefficient $>$

\begin{tabular}{|c|c|c|c|c|c|}
\hline \multicolumn{6}{|l|}{ Coefficients" } \\
\hline \multirow[b]{2}{*}{ Model } & \multicolumn{2}{|c|}{$\begin{array}{l}\text { Unstandardized } \\
\text { Coefficients }\end{array}$} & \multirow{2}{*}{$\begin{array}{l}\text { Standardized } \\
\text { Coefficients } \\
\text { Beta }\end{array}$} & \multirow[t]{2}{*}{ t } & \multirow{2}{*}{ Sig. } \\
\hline & B & Std. Error & & & \\
\hline 1 (Constant) & 31.861 & 7.392 & & 4.310 & .000 \\
\hline Budaya Organisasi (X2) & .467 & .112 & .469 & 4.182 & .000 \\
\hline
\end{tabular}

Based on the simple linear regression test above, the $t$ value is 4.182 . Then the $t$ table value is sought in the $\mathrm{t}$ statistical table with $\alpha=0.05$ and degrees of freedom (df) $n-2$ or $64-2=62$ ( $n$ is the amount of data), the $t$ table results are 1.998. So the value of $t$ count (4.182)> $t$ table (1.998), so that Hol is rejected and Ha1 is accepted. Then for the significance test calculated by the SPSS application program version 25 obtained a significant value of 0.000 . This value is less than 0.05 , so that Ha2 is accepted and Ho2 is rejected. Complete results can be seen in the following Anova table.

Table $2<$ Significance Test Results $>$

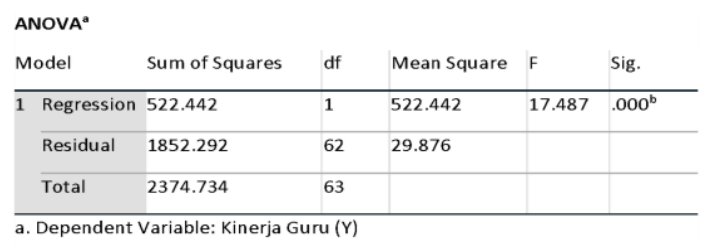


Based on the $t$ test, the $t$ value (4.182) $>\mathrm{t}$ table (1.998) was obtained. Then for the significance test obtained the value of Sig $=0.000<0.05$. The results of the Hypothesis 2 test can be concluded as follows: 1) Ha2 is accepted, meaning that the hypothesis which states that there is a significant effect of organizational culture on the performance of public elementary school teachers in Cluster 1, Rambutan District, is accepted. And 2) $\mathrm{Ho} 2$ is rejected, meaning that the hypothesis which states that there is no significant influence of organizational culture on the performance of the SD Negeri teachers in Cluster 1, Rambutan District, is rejected.

This should build an efficient and high-quality teaching and learning process with a strong and welcoming organizational culture to enhance the quality of education. [11] the culture of the school organization can be realized through significant variables of concrete acts such as as a) obeying and implementing the provisions of working hours; b) carry out the task seriously and responsibly; c) develop positive organizational culture values in schools; d) develop a work culture and discipline culture in the school environment.

In line with the relevant study by Wahidy, et al (2020: 96), which shows the $0.428 \mathrm{R}$ amount. Therefore, it can be said that the culture of the school has a sufficient influence on the standard of teaching of teachers at SMP Negeri 1 Prabumulih, as demonstrated by the importance of the correlation between $0.400-0.599$. Previous research conducted by Fitria (2018: 85-86) in the International Journal Of Scientific \& Technology Research Volume 7, Issue 7, July 2018 stated that “... Organizational culture has a direct positive effect on teacher performance. The findings of this study indicate that organizational culture positively determines teacher performance. The results of this study have given the direction that organizational culture is closely related to teacher performance improvement. From the results of this study it can be concluded that organizational culture in terms of the application of norms, values and behavior in schools greatly determines the improvement of teacher performance

\section{Conclusions}

The research findings show that organizational culture has a substantial impact on the performance of teachers. . This is indicated by the value of tcount of 4.182 and t table of 1.998 where tcount $>t$ table which shows $\mathrm{Ha}$ is accepted so that it is stated that there is a significant influence between organizational culture on the performance of elementary school teachers in cluster 1 of Rambutan District. Organizational culture can encourage teachers to enhance performance both within and outside of school in a better school environment. The principal will have a positive influence on teachers through the progression of the organizational culture.

\section{References}

Arikunto, Suharsimi. 2014. Prosedur Penelitian Suatu Pendekatan Praktik. Jakarta: Rineka Cipta.

Asmani, Jamal Ma'mur. 2012. Tips Sakti membangun Organisasi Sekolah. Jogjakarta: DIVA Press.

Hamalik, Oemar. 2008. Proses Belajar Mengajar.Jakarta: PT. Bumi Aksara.

Hoy, Wayne.K. 2014. Administrasi Pendidikan Teori, Riset, dan Praktek. Yogyakarta: Pustaka Pelajar.

Kesumawati, Nila and Aridanu, Ichwan. 2017. Statistik Parametrik Penelitian Pendidikan. Depok: Rajagrafindo Persada.

Kusmianto. 1997. Paduan Penilaian Kinerja Guru Oleh Pengawas. Jakarta.

Mustari, mohammad. 2013. Budaya Sekolah pada Sekolah Menegah Pertama di Indonesia. Jurnal Kebijakan Pengembangan Pendidikan.Volume1, Nomor 2, Hal 185-193. Diakses 28 November 2020.

Supardi. 2013. Kinerja Guru. Jakarta: Rajawali Pers.

Sugiyono. 2010. Metode Penelitian Kuantitatif, Kualitatif, dan R\&D. Bandung:CV. Alfabeta

Yuliandri, Jimmy and Kristiawan. 2017. Peran Kepemimpinan Kepala Sekolah Terhadap Peningkatan Kinerja Guru.Jurnal Dosen Universitas PGRI Palembang. Diakses 4 November 2020.

Zamroni. 2003. Paradigma Pendidikan Masa Depan. Yogyakarta: BIDRAF. 